Esta obra possui uma Licença

Creative Commons Atribuição-Não Comercial 4.0 Internacional

do https://periodicos.ufpa.br/index.php/revistamargens/article/view/36162

http://dx.doi.org/10.18542/rmi.v15i24.36162

Margens: Revista Interdisciplinar | e-ISSN:1982-5374 | V. 15 | N. 24 | Jun., 2021, pp. 11-12.

\title{
VILA COLINA: pontos de fuga e de lutas
}

\section{Leonardo Rafael Santos Leitão ${ }^{I}$}

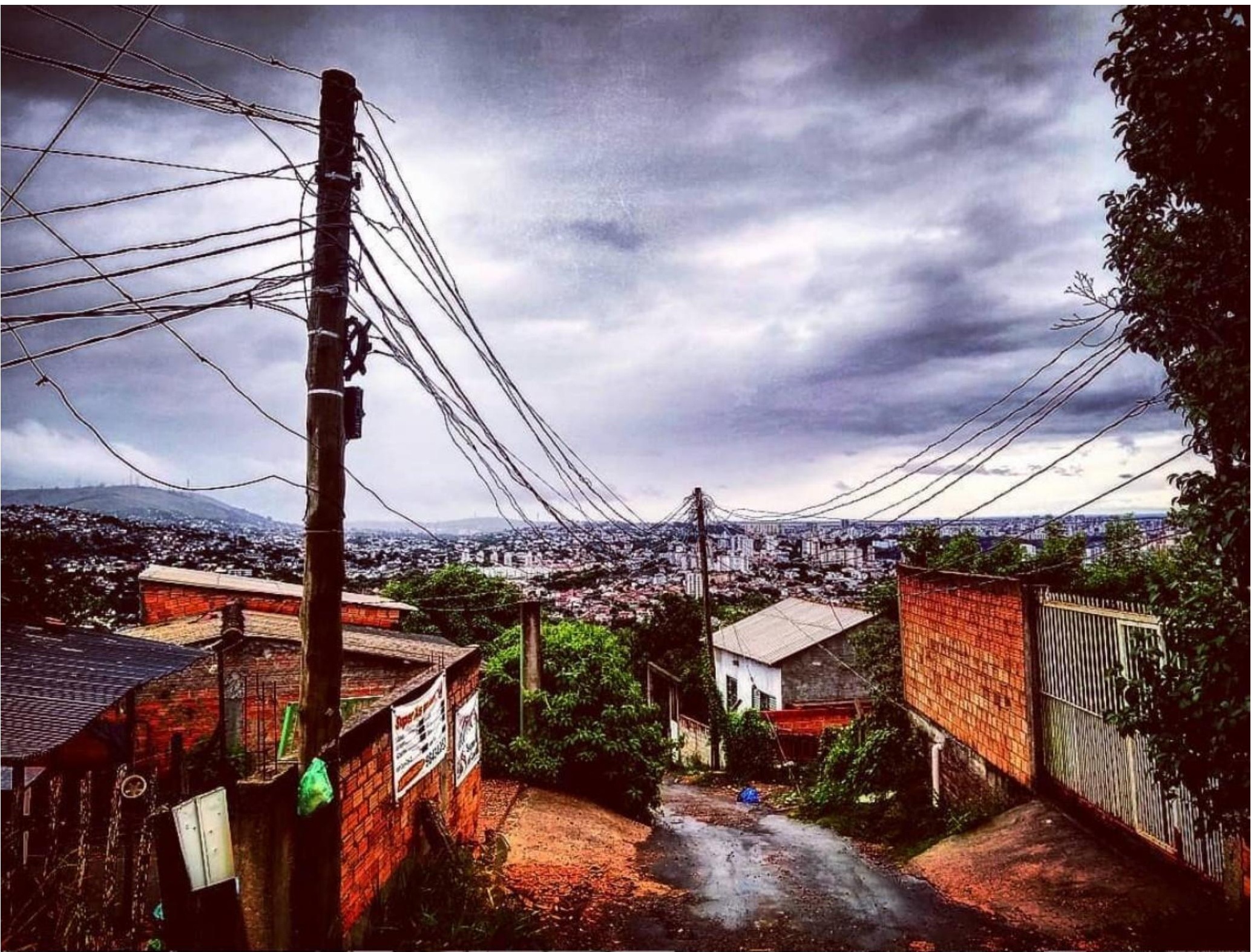

\footnotetext{
${ }^{1}$ Doutor em Sociologia. Professor adjunto da Universidade Federal da Fronteira Sul, campus Chapecó. E-mail
} leonardors1@uffs.edu.br 
O ponto de fuga da imagem, as linhas que buscam orientar o olhar de quem olha para essa fotografia possui muitos significados. Os cabos de energia que partem do topo do Morro Santana, ponto mais alto da cidade de Porto Alegre, se dirigem para um "centro", um centro que radicalmente contrasta com o lugar de onde saem esses cabos. A relação centro e periferia nessa imagem é duplamente importante. Dirige o olhar das margens para o centro e denuncia a desigualdade existente entre centro e periferia nos grandes conglomerados urbanos da América Latina. Essa imagem poderia ser, senão em qualquer lugar de nosso continente, ao menos em muitos e cada vez mais lugares.

Entre esses muitos lugares possíveis, trata-se de um lugar específico, a Vila Colina, situada no topo do Morro mais alto da Cidade de Porto Alegre, o Morro Santana. A ocupação desse espaço do morro, por famílias pobres, trabalhadores e trabalhadoras, está em permanente ameaça. Considerada irregular por parte da prefeitura, a vila está próxima de grandes torres de transmissão de energia e por algumas vezes já foi alvo de intervenção violenta por parte da polícia e da prefeitura para desocupar esse local. A Vila Colina é mais uma entre muitos territórios ameaçados de despejo constante em uma sociedade em que morar passa a ser um privilégio.

Essa imagem foi feita em um dia chuvoso, mas não um dia qualquer. Era um dia de resistência.

Nesse dia a comunidade desceu o topo do morro em direção ao asfalto para mais um, de muitos protestos contra a desocupação. Mesmo embaixo de chuva moradores se manifestaram na Avenida Ipiranga, importante avenida da cidade que fica aos pés do Morro Santana e se estende até as margens do Rio Guaíba.

Fiz essa imagem pois estava prestando solidariedade a luta da Vila Colina. Me criei e vivi por quase trinta anos no entorno desse morro. Ao longo da vida pude ver a expansão desordenada desse espaço. A ocupação por famílias pobres em lugares cada vez mais alto do morro sempre foi reflexo de uma política urbana que desde o fim da escravidão expulsou os mais pobres do centro da cidade os jogando para lugares cada vez mais longe, não apenas do centro, mas de serviços e infraestrutura pública.

Essa pequena história da imagem que ilustra a capa do presente número da Revista Margens é também a história de muitas comunidades que resistem, ainda que em condições das mais adversas, por toda América Latina. Também faz parte de minha história. O enquadramento escolhido para registrar essa fotografia foi dos pontos e linhas de fuga, que também são pontos de luta e resistência. Boitempo, 2020. 